第 10 回硬膜外麻酔研究会シンポジウム

硬膜外腔と広がり

硬膜外腔圧からみた硬膜外麻酔の広がり

平林由広*

\begin{abstract}
[要旨] 硬膜外腔圧と硬膜外麻酔の広がりとの関係について，これまでに報告された 研究を概説した．硬膜外腔に薬液を注入したときに生ずる硬膜外腔の圧変化を椎間孔 の開存性だけで説明することはできない，硬膜外腔の圧変化を頭蓋腔を含めた圧緩衝 システムの応答としてとらえると, 硬膜外腔のコンプライアンスが大きく, 抵抗が小 さいほど,薬液注入によって硬膜外腔の潜在空間が物理的によく広がると考えられる. キーワード：硬膜外麻酔, 硬膜外腔圧
\end{abstract}

(日臨麻会誌Vol.25 No.1, 81 88, 2005)

\section{はじめに}

硬膜外腔に局所麻酔薬を注入すると硬膜外腔圧が 一過性に上昇する。この硬膜外腔の圧上昇が薬液の 広がりに影響するのではないかと考えるのは自然で ある。しかし，硬膜外腔の圧変化と硬膜外麻酔の広 がりとの関係を調べた研究はきわめて少ない.しか も，その関係を肯定する報告と否定するものがある. 本稿ではこれまでの報告を概説し，さらにわれわれ が行ってきた硬膜外腔压の研究結果を加え, 硬膜外 腔の圧変化と硬膜外麻酔の広がりとの関係を考察す る. 本稿における硬膜外腔圧とは, 硬膜外腔に元来 存在する自然の圧ではなく，薬液注入によって発生 する硬膜外腔圧の一過性の変化, あるいは, 注入後 一定時間が経過したときの硬膜外腔の残留圧を示す ことを前置きする。

*自治医科大学麻酔科学・集中治療医学講座

\section{Usubiaga らの報告 ${ }^{1)}$}

硬膜外腔の圧変化と硬膜外麻酔の広がりとの関係 を示唆した最初の報告である。硬膜外腔に薬液を注 入した直後にシリンジを針から外すと，少量の薬液 が逆流してくることがある。この薬液の逆流がしば しば高齢者に多くみられ，しかも麻酔がよく広がる という印象が彼らの研究の動機であった。405名の 患者で硬膜外腔圧が水マノメータで観察された。そ のうち条件の揃つた腰部硬膜外麻酔 112 例で, 硬膜 外腔圧と麻酔の広がりとの関係が検討された。側臥 位で $17 \mathrm{G}-\mathrm{Tuohy}$ 針から $2 \%$ リドカイン $10 \mathrm{ml}$ を 15 秒 で注入し, 硬膜外腔の圧変化を $2 \sim 5$ 分観察した。 若年者では，薬液注入によって上昇した硬膜外腔圧 が注入終了後に急速に減衰した。一方，高齢者では 薬液注入による圧の上昇は若年者より目立たない が，その後の減衰が緩徐で，最終的には残留圧が若 年者より高く保持された。注入 2 分後の硬膜外腔の 


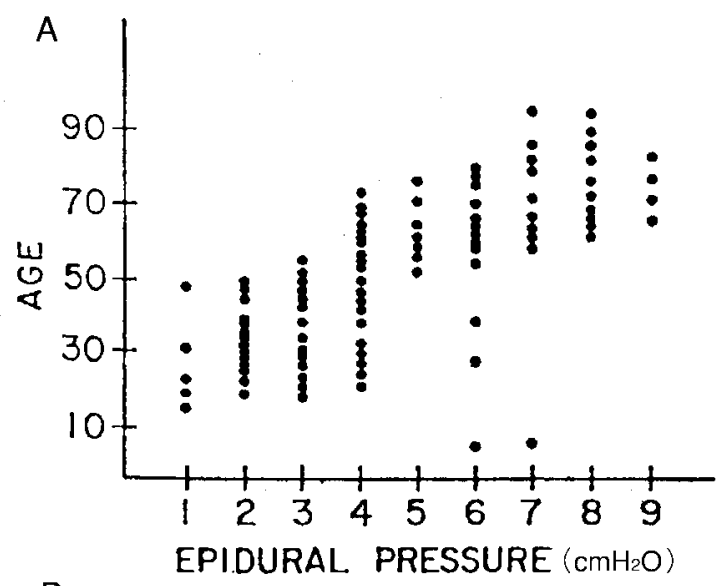

B

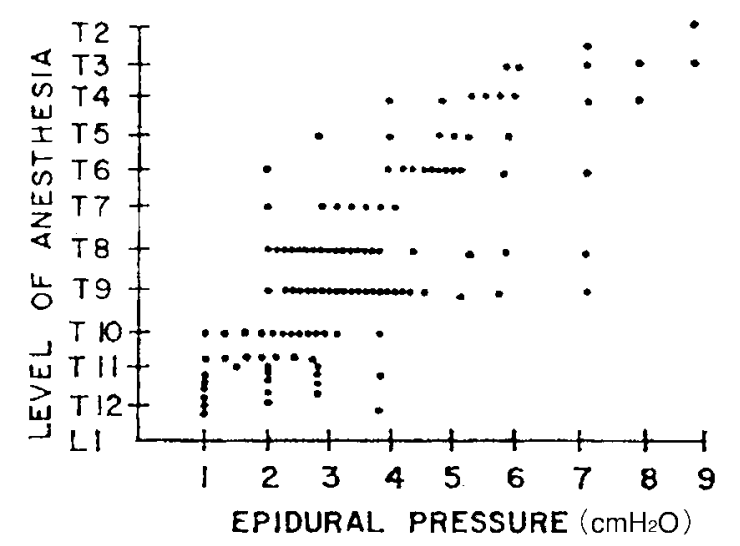

図1 リドカイン $10 \mathrm{ml}$ を硬膜外針から注入して2 分後 の硬膜外腔の残留圧 (epidural pressure)

$\mathrm{A}$ : 残留圧と年齡との関係 $\mathrm{B}$ : 残留圧と麻酔レベル との関係

〔文献1) から許可を得て引用〕

残留圧は，50歳未満が $3.2 \pm 0.31 \mathrm{cmH}_{2} \mathrm{O}(\mathrm{Mean} \pm \mathrm{SE})$, 50 歳以上は $5.9 \pm 0.64 \mathrm{cmH}_{2} \mathrm{O}$ であり，高齢者が有意 に高かった (図1A)。残留圧が高いほど麻酔がよく 広がった (図1B)。彼らは硬膜外腔の圧変化が椎間 孔の開存性に依存すると考察した。椎間孔を通じて 硬膜外腔から傍脊椎腔へ流出する薬液の多寡で麻酔 の広がりを説明した。若年者は椎間孔がより開いて いる. 硬膜外腔から傍脊椎腔への薬液の流出が多く, 薬液注入によって上昇した硬膜外腔圧が急激に減衰 する，硬膜外腔に残留する薬液が少なく，麻酔が頭 側方向に広がりにくい.しかし，麻痺領域のブロッ クの質は均一で, 運動神経ブロックが起こりやすい
と考察した。一方，高齢者では結合組織が椎間孔を 閉塞する．硬膜外腔から傍脊椎腔への薬液の流出が 少なく, 薬液注入によって上昇した硬膜外腔圧が長 時間持続する。傍脊椎腔への流出が少ないため頭側 方向へ薬液がよく広がるが，得られたブロックは均 一ではなく，運動神経ブロックがより少ないと考察 した.

\section{Husemeyer と White の報告2)}

満期妊婦における硬膜外腔の圧変化が連続記録さ れた初めての報告である。薬液の注入速度を変化さ せて, 硬膜外腔圧と硬膜外麻酔の広がりとの関係を 検討した。側卧位で腰部硬膜外麻酔を受けた 17 36 歳, 34 名の妊婦に $1.5 \%$ リドカイン $10 \mathrm{~m} l$ を投与し た。炭酸ガス駆動ポンプを使用して $0.143 〜$ $0.333 \mathrm{~m} l \cdot \mathrm{sec}^{-1}$ の範囲で注入速度を変化させ，それぞ 孔 $17 \mathrm{G}-$ Tuohy 針から定速注入した。薬液注入の最 初から最後まで，さらにその後の圧変化も 2 分間途 切れなく記録された。薬液注入中の回路最高圧は $29.0 \pm 14.0 \mathrm{cmH}_{2} \mathrm{O}(\mathrm{Mean} \pm \mathrm{SD}), 2$ 分後の硬膜外腔 残留圧は $11.4 \pm 3.7 \mathrm{cmH}_{2} \mathrm{O}$ であった。硬膜外麻酔の 広がりと薬液注入中の最高圧および硬膜外腔残留圧 の間に，有意な関係は見出せなかった。薬液の注入 速度を変化させた条件で硬膜外腔圧を測定した場合 には，硬膜外腔圧と麻酔の広がりとの間に有意な相 関は認められなかった。

\section{III＼cjkstart西邑と遠藤の報告 3$)$}

硬膜外カテーテルを経由して硬膜外腔残留圧を測 定した報告である．腰部硬膜外麻酔を行った 20 82 歳, 31 名の患者で, 外径 $1 \mathrm{~mm}$ の硬膜外カテーテ ル経由で, $2 \%$ メ゚バカイン $10 \mathrm{ml}$ を $45 \sim 70$ 秒間で 注入した。その後，压トランスデューサをカテーテ ルに接続して, 注入 2 分後の仰臥位の硬膜外腔残留 圧を測定した。硬膜外腔残留圧と硬膜外麻酔の広が りとの間にやや相関が認められた。とくに，硬膜外 麻酔の広がりと年齢および硬膜外腔残留圧の和との 


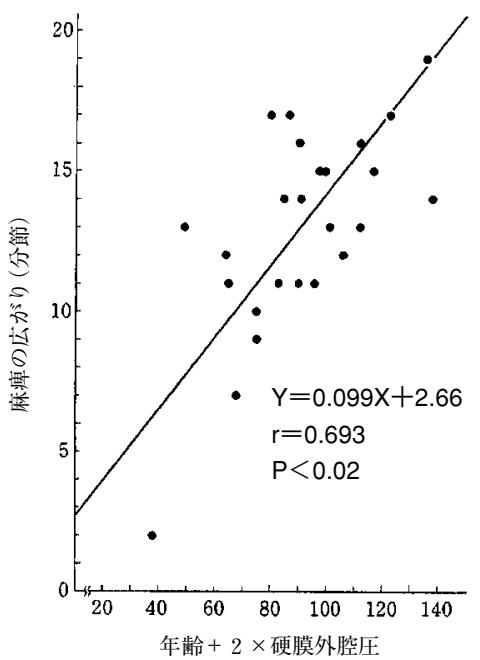

図2メピバカイン $10 \mathrm{ml}$ を硬膜外カテーテルから注入 して2分後のカテーテル経由で測定した硬膜外腔 圧を 2 倍して年齢を足した指標と麻痺分節数との 関係

〔文献3) から許可を得て引用〕

間に強い相関を見出した(図2)。硬膜外腔残留圧が 高いほど麻酔が広がりやすいというUsubiaga らの 報告 ${ }^{1)}$ と一致した。

\section{Paul と Wildsmith の報告 ${ }^{4)}$}

腰部硬膜外腔へ $0.75 \%$ ブピバカインを注入し, 注 入量 $10 \mathrm{~m} l$ と $15 \mathrm{~m} l$ で硬膜外腔の圧変化を比較した報 告である。腰部硬膜外麻酔を受けた 30 名の患者で, 18G-Tuohy 針を通じて硬膜外腔圧を連続記録した。 薬液を $0.5 \mathrm{~m} l \cdot \mathrm{sec}^{-1}$ の速度で注入したときの最高圧 と注入後 1 分の硬膜外腔残留圧を比較した. 薬液注 入中の回路最高圧は $10 \mathrm{~m} l$ 群 $40.3 \pm 14.5 \mathrm{~cm} \mathrm{H}_{2} \mathrm{O}$, $15 \mathrm{~m} l$ 群 $52.9 \pm 14.2 \mathrm{cmH}_{2} \mathrm{O}$ で有意差を認めた。一方, 硬膜外腔残留圧は $10 \mathrm{~m} l$ 群 $17.9 \pm 7.8 \mathrm{cmH}_{2} \mathrm{O}, 15 \mathrm{~m} l$ 群 $18.1 \pm 5.4 \mathrm{cmH}_{2} \mathrm{O}$ であり，有意差がなかった。両群 間の麻酔の広がりに有意差はなかった。薬液注入量 が多いほど硬膜外腔の圧上昇が大きいことが明らか になったが，硬膜外腔残留圧と麻酔の広がりとの間 に有意な相関は認められなかった。
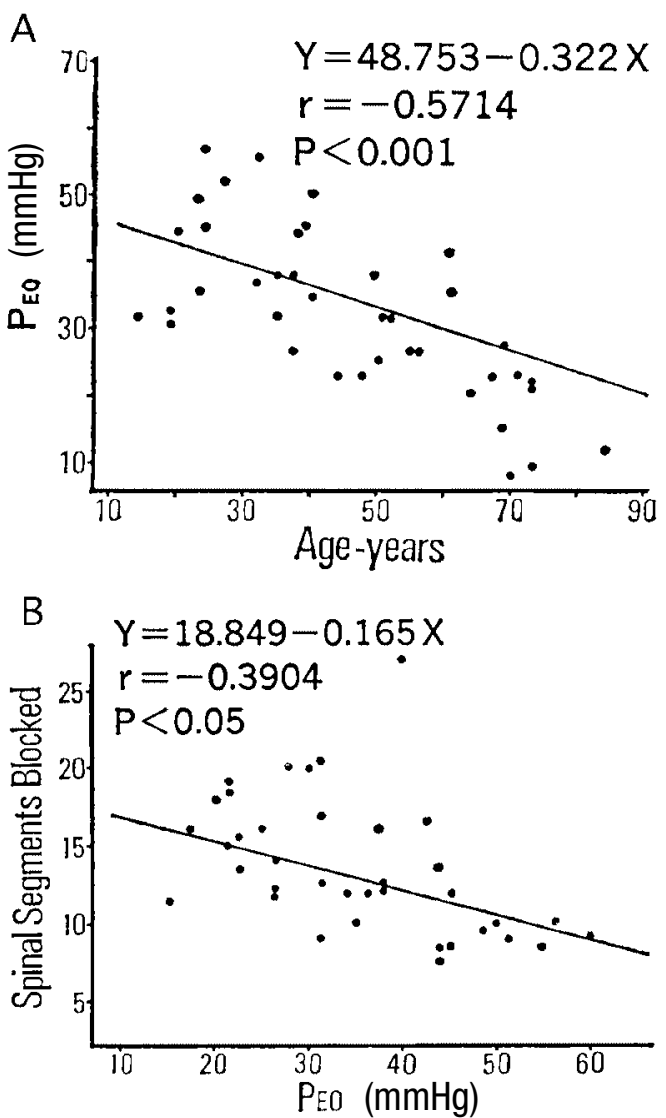

図3メピバカイン $15 \mathrm{~m} l$ を点滴法で定圧注入した直後 の硬膜外腔圧 $\left(\mathrm{P}_{\mathrm{EO}}\right)$

$\mathrm{A} ：$ 年齢と硬膜外腔圧との関係 $\mathrm{B}$ ：硬膜外腔圧と無 痛分節数との関係

〔文献5) から許可を得て引用〕

\section{$\mathrm{V}$ 定圧注入時の硬膜外腔圧と麻酔の広がり ${ }^{5)}$}

点滴セットの滴下速度を指標にして硬膜外穿刺を 行う点滴法 ${ }^{6}$ を利用すると, 局所麻酔薬を一定の圧 で硬膜外腔に注入できる。この方法を用いて $80 \mathrm{mmHg}$ の圧差で $2 \%$ メピバカイン $15 \mathrm{~m} l$ を腰部硬 膜外に定圧注入したときの硬膜外腔圧を連続測定し た。薬液は $17 \mathrm{G}-\mathrm{Tuohy}$ 針を通じて $1.01 \pm 0.06 \mathrm{~m} l$ ・ $\mathrm{sec}^{-1}$ で注入され, 注入中の回路圧は $73.3 \pm 0.8 \mathrm{mmHg}$ であった。注入直後の硬膜外腔圧は $33.9 \pm 1.7 \mathrm{mmHg}$ であり，その後は経時的に減衰し注入 1 分後の残留 压は $11.4 \pm 0.8 \mathrm{mmHg}$ であった。注入直後の硬膜外 腔圧は高齢者が低かった (図 $3 A$ )。注入直後の硬膜 

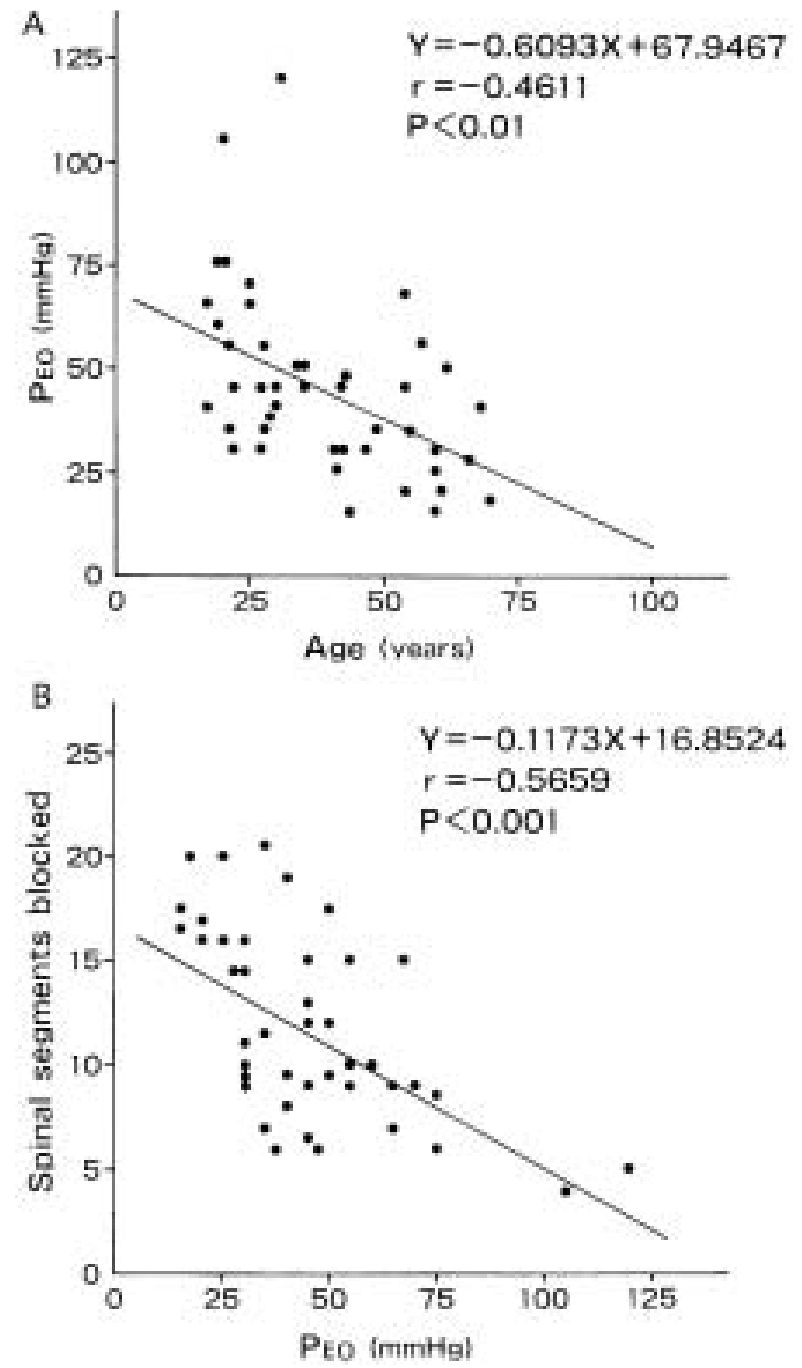

図4 メピバカイン $15 \mathrm{ml}$ をシリンジポンプで定速注入 した直後の硬膜外腔圧 $\left(\mathrm{P}_{\mathrm{EO}}\right)$

$\mathrm{A}$ ：年齢と硬膜外腔圧との関係 $\mathrm{B}$ ：硬膜外腔圧と無 痛分節数との関係

〔文献6) から許可を得て引用〕

外腔圧と麻酔の広がりに有意な負の相関が認めら れ, 注入直後の硬膜外腔圧が低いほど麻酔が広がっ た (図 3B)。この負の相関は薬液の注入直後の硬膜 外腔圧だけで確認でき，その後は消失した。薬液を 定圧注入した場合には，薬液を注入し終わった時点 での硬膜外腔圧が低いほど麻酔が広がりやすい。

\section{VI 定速注入時の硬膜外腔圧と麻酔の広がり ${ }^{7)}$}

シリンジポンプを使用して局所麻酔薬を硬膜外腔
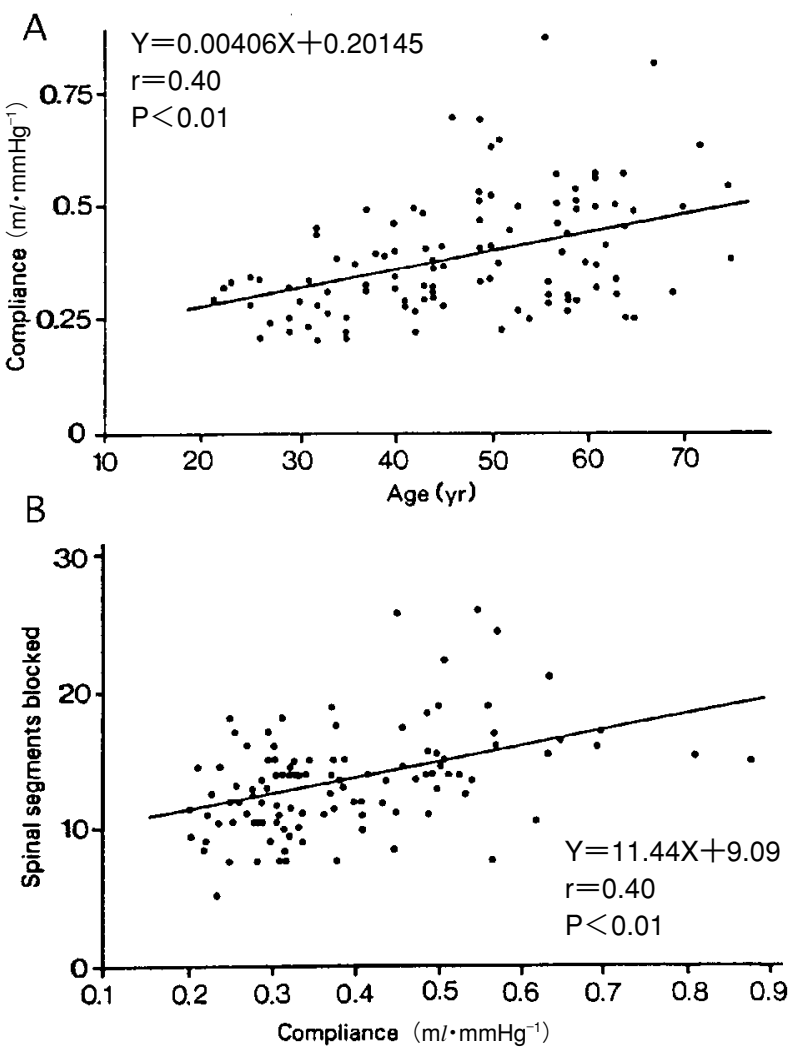

図 5 硬膜外腔のコンプライアンス

$\mathrm{A} ：$ 年齢とコンプライアンスとの関係 B：コンプラ イアンスと無痛分節数との関係

〔文献8) から許可を得て引用〕

へ定速注入し，硬膜外腔の圧変化を連続記録した。 $2 \%$ メ゚バカイン $15 \mathrm{~m} l$ を $1 \mathrm{~m} l \cdot \mathrm{sec}^{-1}$ の速度で $17 \mathrm{G}^{-}$ Tuohy 針を通じて腰部硬膜外腔へ注入した。薬液注 入中の回路圧は，初圧 $69.3 \pm 25.2 \mathrm{mmHg}$ から終圧 $98.3 \pm 21.3 \mathrm{mmHg}$ に上昇した。注入直後の硬膜外腔 圧は $44.6 \pm 1.7 \mathrm{mmHg}$ ，その後は経時的に減衰し注 入 1 分後の硬膜外腔残留圧は $10.9 \pm 4.1 \mathrm{mmHg}$ となっ た。定速注入に伴って発生した硬膜外腔の圧上昇は 高齢者ほど小さかった (図4A)，硬膜外腔圧と年齢 との間には有意な負の相関が認められ。この負の相 関は薬液注入後 50 秒間観察された。硬膜外腔圧と 麻酔の広がりとの間にも有意な負の相関が認めら れ，硬膜外腔圧が低いほど麻酔が広がった(図4B)。 この有意な負の相関は薬液注入後 60 秒間認められ た。薬液を定速注入した場合にも，定圧注入時と同 

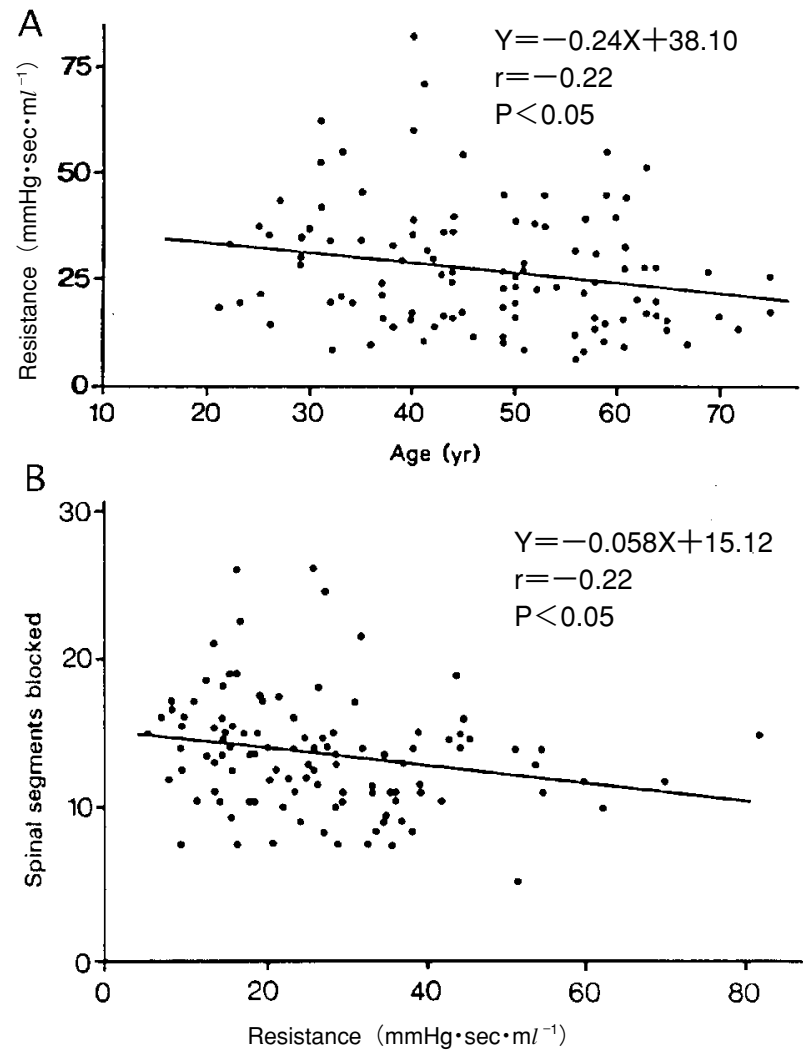

図6 硬膜外腔の抵抗

$\mathrm{A}$ ：年齢と抵抗との関係 $\mathrm{B}$ ：抵抗と無痛分節数との 関係

〔文献8) から許可を得て引用〕

様，硬膜外腔の圧が低いほど麻酔が広がりやすい.

\section{VII＼cjkstart硬膜外腔のコンプライアンス および抵抗と麻酔の広がり ${ }^{8)}$}

硬膜外腔に急速に薬液を注入したときに生ずる圧 応答曲線にウインドケッセル理論を応用して硬膜外 腔のコンプライアンスと抵抗を算出した。腰部硬膜 外麻酔を受けた 111 名の患者を対象にした。17GTuohy 針 2 本を隣接した椎間に留置し, 一方から薬液 を注入し，他方で硬膜外腔圧を測定した． $2 \%$ メ゚バ カイン $10 \mathrm{~m} l$ を $2.3 \pm 0.7$ 秒で注入した。算出された 硬膜外腔コンプライアンスは $0.39 \pm 0.13 \mathrm{~m} l \cdot \mathrm{mmHg}^{-1}$ であった，硬膜外腔コンプライアンスは高齢者が大 きかった (図 5A)。硬膜外腔コンプライアンスが大 きいほど，麻酔が広がり，有意な相関が認められた
(図5B)，硬膜外腔抵抗は $26.8 \pm 14.5 \mathrm{mmHg} \cdot \mathrm{sec} \cdot \mathrm{m} l$ 1であった。硬膜外腔抵抗は高齢者が小さかった（図 $6 \mathrm{~A}$ )。硬膜外腔抵抗が小さいほど麻酔が広がった(図 $6 \mathrm{~B})$. 硬膜外麻酔がよく広がる高齢者では，硬膜外 腔のコンプライアンスが大きく, 抵抗が小さかった。

\section{Cardoso の報告 ${ }^{9)}$}

薬液の注入速度と硬膜外腔圧との関係を検討し た. 20 名の妊娠初期の患者で， $2 \%$ リドカイン $15 \mathrm{ml}$ を 30 秒間と 3 分間で注入したときの硬膜外腔の圧変 化を比較した。薬液注入に伴う硬膜外腔の圧上昇は 30 秒注入群が 3 分注入群より有意に高かったが，注 入後 30 秒以降の硬膜外腔残留圧は両群に有意差は 認められなかった. 3 分注入群の最高圧と温覚遮断 域の広がりとは有意な負の相関が認められた。また, 両群ともに, 3 分後の硬膜外腔残留圧と温覚遮断域 の広がりとの間に有意な負の相関が認められた。 30 秒注入群では痛覚遮断域と硬膜外腔残留圧に負の相 関が認められた。しかし，この負の相関は観察時間 中に常に証明できるものではなかった。硬膜外腔残 留圧と麻酔の広がりとの関係では, 痛覚遮断域より 温覚遮断域の方が有意な関係を確認しやすく, 硬膜 外腔圧と広がりに有意な負の相関があった。

\section{IX 硬膜外腔コンプライアンス}

Bromage は著書『Epidural Analgesia』のなかで硬 膜外腔コンプライアンスの概念を提唱した ${ }^{10)}$. 高齢者 は硬膜外腔コンプライアンスが小さく, 硬膜外腔コ ンプライアンスの減少が薬液の広がりをよくすると いう仮説である。加齢とともに椎間孔が結合組織で 閉塞し, 硬膜外腔から傍脊椎腔への薬液の流出が少 なくなる。このため高齢者では硬膜外腔残留圧が高 く, 硬膜外腔コンプライアンスが小さいと推定した。 薬液注入に伴って上昇する硬膜外腔圧が年齢によっ て異なり，高齢者は若年者より硬膜外腔圧が高く推 移する図を発表した(図7)。この図はUsubiaga らの 1967 年の報告 ${ }^{1)}$ に基づき作成されているが，原図と 


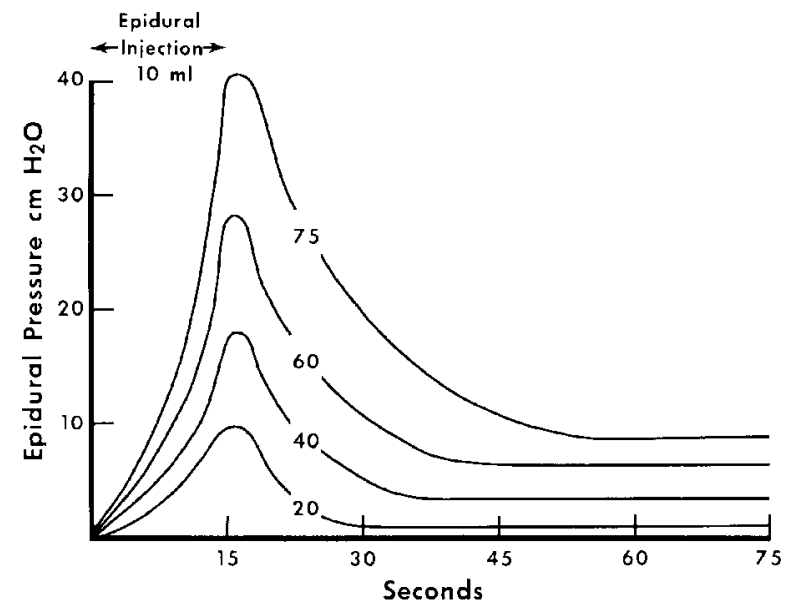

図7リドカイン $10 \mathrm{ml}$ を 15 秒で硬膜外腔に注入したと きの硬膜外腔圧の年齢別の経時変化

〔文献10) から許可を得て引用〕

多少異なる点が指摘できる，原図では，注入中の硬 膜外腔の最高圧は若年者が高齢者より高い。しかし， 注入が終了すると若年者の硬膜外腔圧が急激に減衰 する。一方，高齢者の圧の減衰は緩徐であるため, 注入後しばらく経過した時点の硬膜外腔残留圧は高 齢者が若年者より高くなる。引用図では薬液注入の 最初から若年者の圧が低く描記され，若年者では椎 間孔が開いているため硬膜外腔圧が低いと解説した。

硬膜外腔から傍脊椎腔に流出する薬液量が椎間孔 の開存度によって規定され, 麻酔の広がりが決まる という仮説は理解しやすい. しかし, 加齢に伴って 椎間孔が閉塞していく現象はいまだに証明されてい ない. 造影剂を硬膜外腔に注入すると高齢者では造 影剤が硬膜外腔の長軸方向によく広がる。しかし， 造影剤の椎間孔からの漏れの程度と年齢との間に有 意な関係は認められない ${ }^{11), 12)}$ 。椎間孔の開存度だ けで硬膜外腔の圧変化と薬液の広がりとの関係を説 明することはできない.

われわれが算出した硬膜外腔コンプライアンスは 高齢者で大きく, Bromageの概念に相反した。同時 に算出した硬膜外腔抵抗は高齢者で小さかった。薬 液注入直後に測定された硬膜外腔圧も高齢者が低か った。これらは何を意味するのであろうか. 硬膜外
腔は硬膜 の外側で，脊柱管の内壁を覆う種々の勒 帯との間の潜在的な隙間である。脂肪組織，結合組 織，血管，神経など少量の組織が存在する．椎間孔 を介して傍脊椎腔へ連絡するが，基本的に脊柱管と いうかぎられた容積の空間に存在し，外側に広がる ことはできない。硬膜外腔に注入された薬液は硬膜 を内側に圧迫して，春柱管内壁を覆う勒帯から硬膜 を がし隙間を広げる。薬液注入に伴って発生する 硬膜外腔の圧はさまざまな因子に規定される。これ らは施術者が規定できる外的因子と，施術者が規定 できない患者側の内的因子に分けられる。患者側の 因子はこれまで椎間孔の開存度が主と考えられてき た。しかし，そのほかにも硬膜外腔を埋める脂肪組 織や結合組織の状態, 硬膜そのものの状態, 脳実質 と脳脊髄液あるいは脳圧など硬膜 の内側の状態, さらに硬膜外腔の静脈叢の状態などさまざまな因子 が関係する。われわれが算出した硬膜外腔コンプラ イアンスは，外から注入された薬液が硬膜外腔とい う潜在的な隙間を押し広げる作用に対するこれらさ まざまな因子の総合的な指標と考えられる。硬膜外 腔コンプライアンスが大きく, 硬膜外腔抵抗が小さ い高齢者では，硬膜外腔に薬液が注入されたときに 硬膜外腔の隙間が広がりやすく，薬液が物理的によ く広がると考えられる。

高齢者で硬膜外腔コンプライアンスが増加し，硬 膜外腔抵抗が減少する理由は明らかではないが，わ れわれは以下の二つが関係すると考えている。第一 番目は硬膜外腔を埋めている組織の状態である。硬 膜と黄色勒帯との間には，脂肪組織と結合組織が存 在する．硬膜と黄勒帯との間を がすために必要な 力はこの両者を結ぶ組織の性状に直接関係する。若 年者の硬膜外腔は脂肪組織と結合組織によって硬膜 と黄勒帯とが密に結合している ${ }^{13)}$. 高齢者では脂肪 組織も結合組織も疎になり，両者間の結合が弱くな りがれやすい. 少量の空気を硬膜外腔に注入して 硬膜外腔を内視鏡で観察すると，高齢者の硬膜外腔 の脂肪組織と結合組織は若年者に比べて少ない ${ }^{14)}$. 
この硬膜外腔鏡所見は本特集の別項で解説されてい るので参照していただきたい．第二番目は硬膜 の 内側に含まれる組織の状態である ${ }^{15)}$ 。硬膜外腔に注 入された薬液は硬膜を外側から内側へ押す。この硬 膜外腔の圧上昇に呼応して脳脊髄液が頭側に移動 し, 硬膜 が細くなり硬膜外腔が広がる ${ }^{16)}$ 。 かぎら れた容積である脊柱管のなかで硬膜外腔が広がるに は硬膜 の狭小化が不可欠である。頭蓋腔は解剖学 的には閉鎖腔であるが，脳循環，髄液の循環，さら に脳血管の緊張性の三者が生理的に作用し，少量の 容積拡大に対してはあたかも開放腔に類似した反応 形態を示す ${ }^{17)}$. 硬膜外腔の容積増加に伴う圧上昇が 脳春髄液の頭側への移動によって緩衝されている. 加齢に伴う脳実質の萎縮, 脳循環, 髄液循環などの 中枢神経系の変化が硬膜外腔のコンプライアンス増 加に関係するのではないかと推定しているが，今後 の検証が必要である.

\section{まとめ}

硬膜外腔の圧変化と硬膜外麻酔の広がりとの関係 を調べた研究結果は，いまだに一定の見解が得られ ていない，硬膜外腔に薬液を注入したときに生ずる 圧変化を椎間孔の開存性だけでは説明することはで きない，硬膜外腔の圧変化を頭蓋腔を含めた圧緩衝 システムの応答と考えると, 高齢者では硬膜外腔の コンプライアンスが大きく, 抵抗が小さい。薬液注 入によって硬膜外腔が物理的によく広がり, 麻酔が 広範囲に及ぶと考えられる。

\section{参考文献}

1) Usubiaga JE, Wikinski JA, Usubiaga LE : Epidural pressure and its relation to spread of anesthetic solutions in epidural space. Anesth Analg 46:440 446, 1967

2) Husemeyer RP, White DC : Lumbar extradural injection pressures in pregnant women. An investigation of relationships between rate of injection, injection pres- sures and extent of analgesia. Br J Anaesth 52:55 60, 1980

3）西邑信男，遠藤正宏：硬膜外麻酔に扔ける硬膜外圧と 麻痺の拡がり。麻酔 33 ：980 982，1984

4) Paul DL, Wildsmith JA : Extradural pressure following the injection of two volumes of bupivacaine. $\mathrm{Br} \mathrm{J}$ Anaesth $62: 368 \sim 372,1989$

5）平林由広, 吉沢由利子, 小川尚德ほか：点滴注入法に よる頸部・胸部および腰部硬膜外麻酔の拡がりと硬膜 外圧. 麻酔 $35 ： 440 \sim 445 ， 1986$

6) Hirabayashi $Y$, Matsuda I, Inoue $S$, et al. : A new technique of identifying the epidural space "dripping infusion method”. J Anesth $3: 105 \sim 108,1989$

7) Hirabayashi $\mathrm{Y}$, Matsuda I, Inoue S, et al. : Epidural pressure and its relation to spread of epidural analgesia. J Anesth 2: 168 172, 1987

8) Hirabayashi Y, Shimizu R, Matsuda I, et al. : Effect of extradural compliance and resistance on spread of extradural analgesia. Br J Anaesth 65 : 508 513, 1990

9) Cardoso MM, Carvalho JC : Epidural pressures and spread of $2 \%$ lidocaine in the epidural space : Influence of volume and speed of injection of the local anesthetic solution. Reg Anesth Pain Med 23 : 14 19, 1998

10) Bromage PR : Epidural pressures, Epidural Analgesia. W.B. Saunders, Philadelphia, 1978, 173

11) Saitoh K, Hirabayashi Y, Shimizu R, et al. : Extensive extradural spread in the elderly may not relate to decreased leakage through intervertebral foramina. $\mathrm{Br}$ J Anaesth $75: 688 \sim 691,1995$

12）齋藤和彦, 平林由広, 堀口祐司ほか：腰部硬膜外腔に 注入された造影剤の椎間孔からの“漏れ”と加齢の関 係. 麻酔 $44: 66 \sim 69,1995$

13) Southworth JL, Hingson RA, Pitkin WM : Extradural anesthesia, Conduction Anesthesia. L.B. Lippincott, Philadelphia, 1946, 731

14) Igarashi $T$, Hirabayashi $Y$, Shimizu R, et al. : The lumbar extradural structure changes with increasing age. Br J Anaesth $78: 149 \sim 152,1997$

15）浅野真, 大岡卓司，小坂義弘：硬膜外腔圧と脳脊髄液 圧の関係．麻酔 $36 ： 89 \sim 93 ， 1987$

16) Takiguchi $T$, Okano $T$, Egawa $H$, et al. : The effect of epidural saline injection on analgesic level during combined spinal and epidural anesthesia assessed clinically and myelographically. Anesth Analg 85 : 1097 1100, 1997

17）池山淳, 前田成, 坂野公一ほか：正常頭蓋内圧環境-開 放腔と開鎖腔の理論-。脳と脊䯣 $28 ： 539 \sim 547,1976$ 


\title{
Epidural Pressures and Spread of Epidural Anesthesia
}

\author{
Yoshihiro HIRABAYASHI \\ Department of Anesthesiology and Critical Care Medicine, Jichi Medical School
}

\begin{abstract}
The author overviewed the reports that covered the relationship between epidural pressure and the spread of epidural anesthesia, and found no evidence that the patency of the intervertebral foraminae was directly related to the epidural pressure after epidural anesthetic injection. Epidural compliance and epidural resistance may have an important role in determining the epidural pressure after epidural anesthetic injection.
\end{abstract}

Key Words : Epidural anesthesia, Epidural pressure

The Journal of Japan Society for Clinical Anesthesia Vol. 25 No.1, 2005 